A new system to control a 630-ton and a 2500-ton presses has been developed. By using this system it has been made possible to define new parameters related to pressure and temperature and the influence of certain factors on them. Furthermore, the new system has been shown to indicate that other parameters, such as height of the gasket formed, electrical resistance of the reaction cell, and the frequency of activation of the pump or multiplier, can serve as important indicators of the improvement of superhard material production technologies, implementing the Computational Intelligence.

Keywords: high pressure, superhard materials, synthesis, sintering, press, high-pressure apparatus, command.

\title{
PARAMETERS EVALUATED
}

When analyzing the curves of the graphs of the parameters and of the height of a gasket $h_{c}$, we can see that there is a difference between these curves, for variable productivities (scale for enlarged $h_{c}$ ). The behavior features of the parameters $p_{1}, I, V, W, R$ and $h_{c}$ during synthesis, are shown in Figs. 1 (no yield) and 2 (with the maximum yield of diamonds). In general, the records of the distance between the high-pressure apparatus (HPA) components show the following steps:

- fast approach of the HPA components;

- elastic and plastic deformation of the capsule;

- formation of the gasket under pressure $p_{1}=66-70 \mathrm{MPa}\left(p_{2}\right.$ from 3.0 to 3.2 GPa);

- elastic deformation of the gasket during the subsequent pressure increase up to $5.0 \mathrm{GPa}$;

- pressure release and removal of the HPA components after the synthesis.

The $h_{c}$ curve shows no increase of the gasket critical thickness during the synthesis, only its reduction. This indicates that there is no increase of the pressure within the compression chamber due to the thermal expansion of the mixture, as described in [1]. The behavior of the approximating curve may be caused by the dimensions of the graphite porosity, the alloy melting and filling graphite pores as well as to the initial formation of diamond nucleus.

From the analysis of the graphs shown in Figs. 1 and 2, we can state that:

- there is a difference between the curves of electric resistance, power, and voltage of the reaction mixture for each operation. According to Fig. 1, for $200 \mathrm{~s}$ after setting the controlled current of heating, the electrical resistance remains constant. Figure 2 shows that the electric resistance reaches its lowest level in $200 \mathrm{~s}$ and after $50 \mathrm{~s}$ increases and becomes constant;

(c) L. O. TAVARES, W. S. VIANNA, G. S. BOBROVNITCHII, A. L. D. SKURY, J. J. A. RANGEL, 2012 
- the registrated curves of the distance change $\left(h_{c}\right)$ between the components of HPA during the process have different characters. The process without the diamond production presents the formation of a gasket under hydraulic pressure $p_{1}$ of $70 \mathrm{MPa}$ and, after reaching the level of the electrical current for the synthesis, the distance between the HPA components is reduced by $0.1 \mathrm{~mm}$. The time of this event is $200 \mathrm{~s}$;

- during the synthesis with productivity, the decrease of the $h_{c}$ between the components of the HPA was $0.4 \mathrm{~mm}$ and took $100 \mathrm{~s}$. This may be caused only by the pressure decrease in the compression chamber of the HPA due to the transformation of graphite into diamond, with the elastic deformation of the gasket and the increase of contact pressure on it, since the force of the press is not changed.

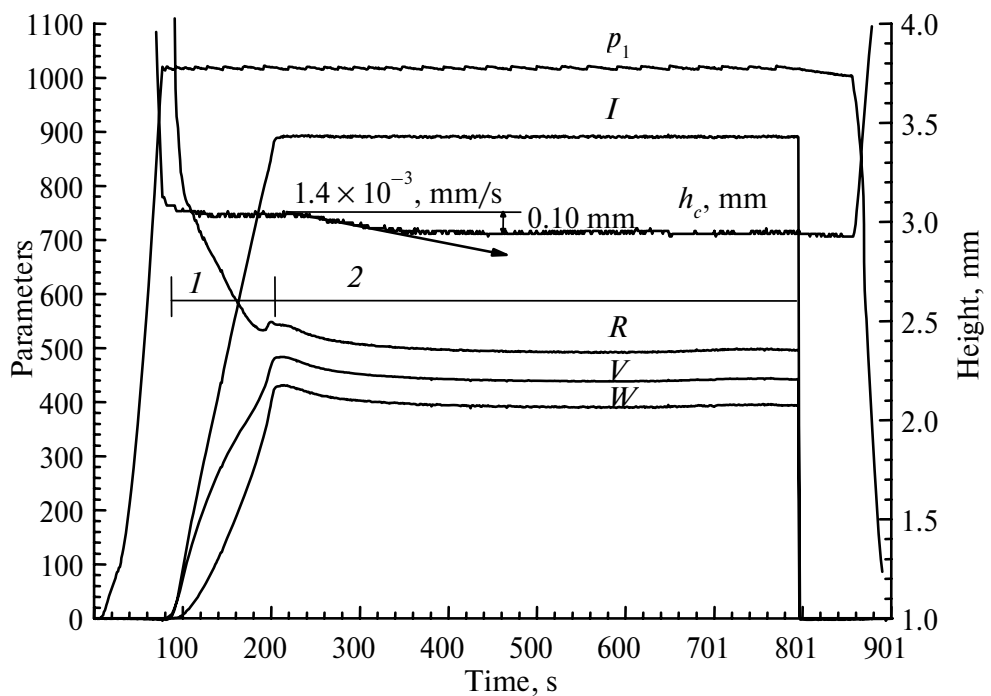

Fig. 1. Parameters $p_{1}, \mathrm{MPa} \times 10 ; I, \mathrm{~A} ; h_{c} ; \mathrm{mm} \times 10 ; R, \Omega \times 10^{5} ; V, \mathrm{~V} \times 10^{2}$; and $W, \mathrm{~W} \times 10^{-1}$, during the synthesis process without productivity.

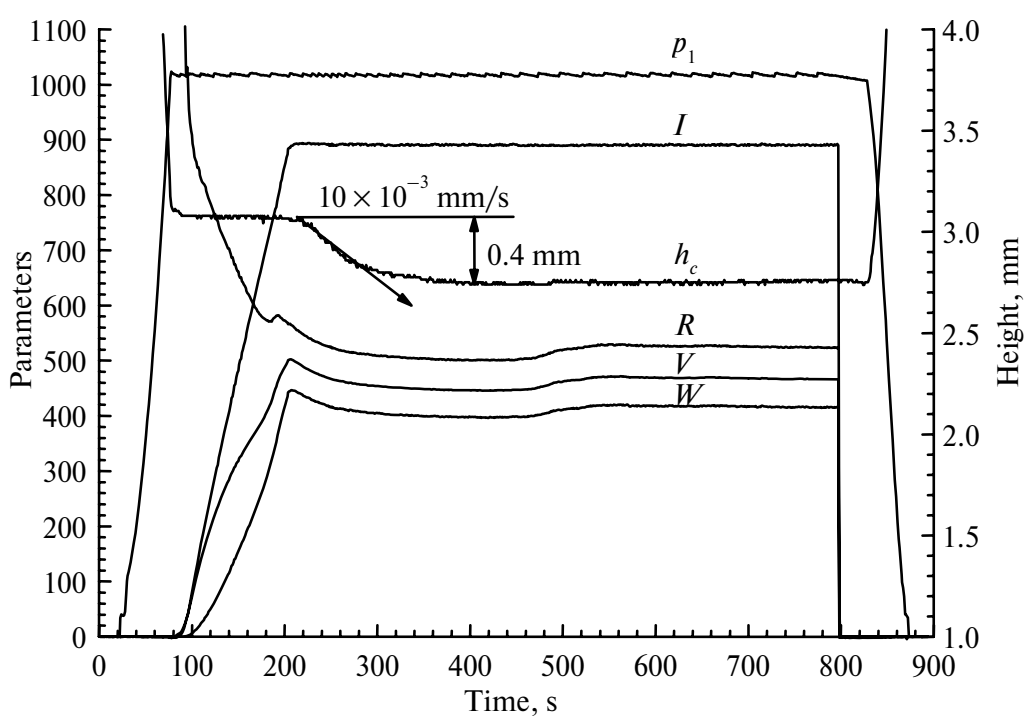

Fig. 2. Parameters $p_{1}, I, h_{c}, R, V$, and $W$ (see Fig. 1 ) during the synthesis with the maximum final yield. 
If the pressure, $p_{1}$, increases linearly in the master cylinder from $102 \mathrm{MPa}$, with a speed of $0.3 \mathrm{MPa} / \mathrm{min}$ from the beginning of heating, it is possible to increase the pressure within the compression chamber.

The characteristics of the typical behavior of the direct parameters $\left(p_{1}, I, R, V\right.$, $W$, and $h_{c}$ ), during synthesis are shown in Fig. 3 (maximum productivity of 6.7 g).

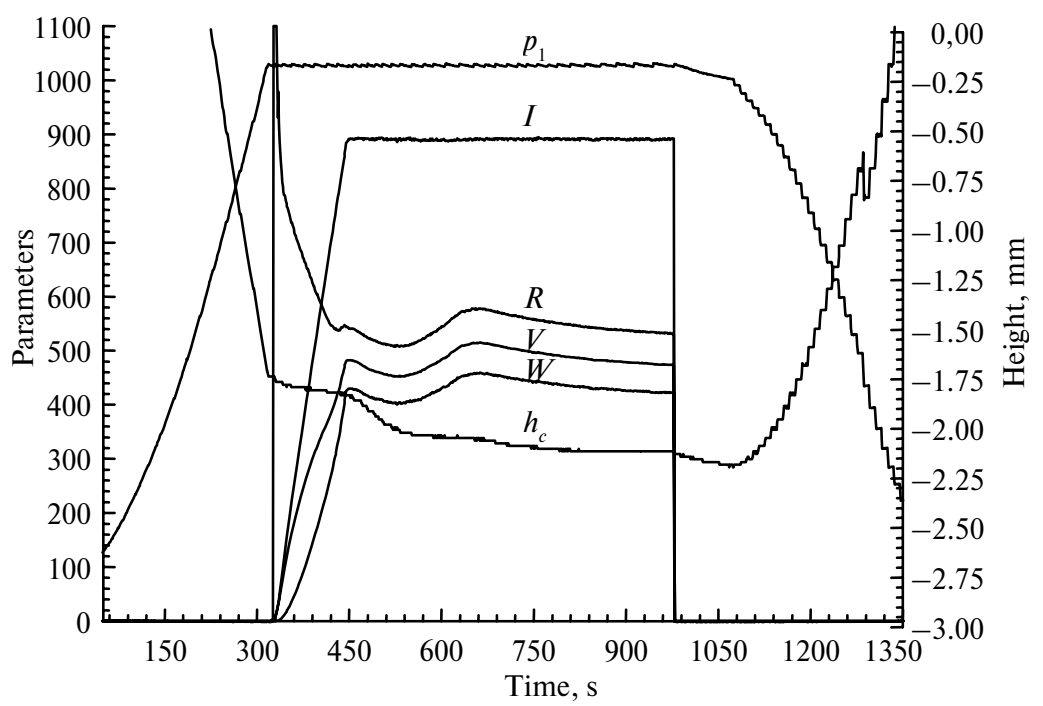

Fig. 3. Curves of the main parameters (see Fig. 1) of the process during the diamond synthesis.

With the increase of pressure $p_{1}$ up to $105 \mathrm{MPa}$ in the master cylinder, critical height $h_{c}$ ranges intensively. In this case, the pressure value in the gasket increases faster, causing plastic deformation in the peripheries of the anvils [2]. In any case, there is a correlation between pressure $p_{1}$ and $h_{c}$.

A way of evaluating the pressure during the diamonds synthesis by correlating the gasket height with the pressure generated within the compression chamber before heating was proposed in [3]. But the linear shape of this dependence does not correspond to the reality of the gasket deformation found in this study. The approximating curve of the HPA parts, constructed in this paper, in accordance with the calibration data made under a temperature of $30^{\circ} \mathrm{C}$, can serve as an indicator of high pressure within the compression chamber for each operation (Fig. 4). This and other dependences (see Figs. 1-3) show that $h_{c}$ is a parameter that can serve for the evaluation of the processes from the operator's point of view as to the future of the Computational Intelligence (CI) in the programming of the command through the equation and appropriate conditions.

With the variations of size and weight of the assembled capsules depending on the gasket critical height and the productivity by operation, some results of the automatic process of diamond synthesis are shown in Table 1. This is caused both by the pressure and temperature change during the process. Comparing the change in weight of the assembled capsule with recorded parameters of the synthesis (see Figs. 1, 2, 5, and 6), it can be concluded that the value of electrical resistance and the critical thickness of the deformed gasket are connected to each other and influence the operation result.

Of course, the main parameters depend, as is seen in Table 1, on the properties of the deformable capsule material, the reaction mixture, the insulating covers and other reaction cell components. Among them, the electrical resistance, 
compressibility, density, and dimensions of each component of the assembled capsule are emphasized. To keep them in equality is impossible, because the mass production does not allow it. It may be necessary to select components in groups and for each group apply more appropriate parameters, which can be found by the CI.

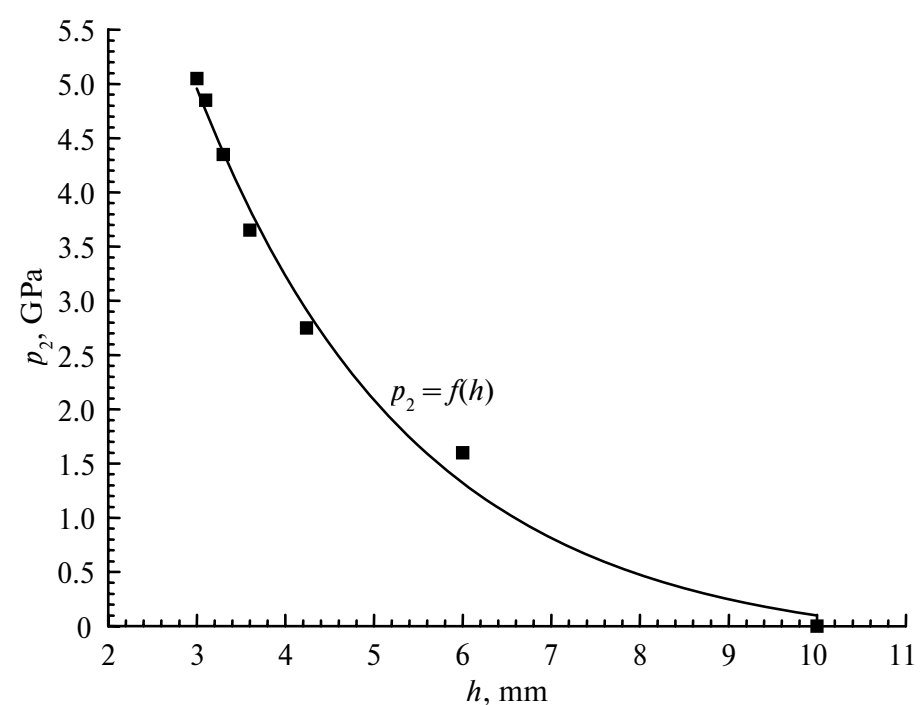

Fig. 4. Pressure in the compression chamber as a function of the distance between the HPA components under the common environmental conditions.

Table 1. Results of the automatic synthesis process and the behavior of its parameters

\begin{tabular}{|c|c|c|c|c|c|c|}
\hline $\begin{array}{l}\text { Synthesis } \\
\text { products }\end{array}$ & $\begin{array}{c}\text { Initial height } \\
\text { of the } \\
\text { capsule } \\
\mathrm{mm}\end{array}$ & $\begin{array}{c}\text { Initial weight } \\
\text { of the } \\
\text { capsule, g }\end{array}$ & $\begin{array}{c}p_{1} \\
\mathrm{MPa}\end{array}$ & $I, A$ & \begin{tabular}{|c|} 
Critical \\
height of the \\
gasket, $\mathrm{mm}$
\end{tabular} & $\begin{array}{c}\text { Average } \\
\text { productivity } \\
\text { of an operation, } g\end{array}$ \\
\hline $\begin{array}{c}\text { Without } \\
\text { diamonds, } 1 \text { unit }\end{array}$ & 30.26 & 150.36 & 102 & 950 & 2.98 & 0 \\
\hline $\begin{array}{l}\text { Diamonds in the } \\
\text { center, } 3 \text { units }\end{array}$ & 30.38 & 146.94 & 102 & 955 & 3.05 & 3.6 \\
\hline $\begin{array}{l}\text { Diamonds in the } \\
\text { periphery, } 3 \text { units }\end{array}$ & 30.45 & 155.21 & 103 & 960 & 2.85 & 4.4 \\
\hline $\begin{array}{l}\text { Diamonds in the } \\
\text { entire section, } \\
43 \text { units }\end{array}$ & 29.78 & 148.80 & 104 & 960 & 2.75 & 6.1 \\
\hline
\end{tabular}

As mentioned, the behavior of the curve of the pressure in the master cylinder drew our attention. Figure 7 shows, in detail, typical curves of the maintenance of pressure $p_{1}$ in the processes carried out without heating, with heating, and with a high and low productivity. Analyzing the curve of the synthesis with high productivity after setting the level of the synthesis current, the frequency of linkage of the pressure multiplier increases and simultaneously reduces the height of the gasket according to curves $h_{c}$ of the synthesis process (see Figs. 1, 2, 5, and 6). 
By increasing the scale of the $p_{1}$ curves in the graphs shown in Figs. 1, 2, 5, and 6 , it can be confirmed that there is a change in pressure $p_{1}$ presented by a cyclic variation of the pressure with amplitude of 0.6 MPa in Fig. 7. The profiles of these changes for each productivity are different and can be used for evaluation of the operation by the future CI.

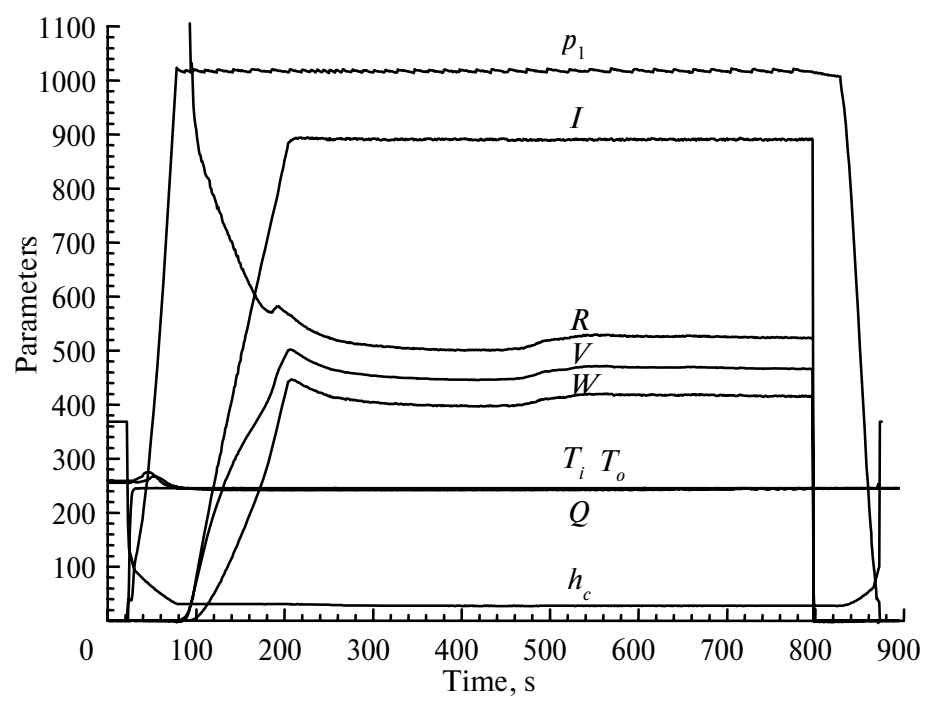

Fig. 5. Curves of the parameters (see Fig. $1 ; Q,-1 / h \times 10^{2} ; T_{i},{ }^{\circ} \mathrm{C} \times 10 ; T_{o},{ }^{\circ} \mathrm{C} \times 10$ ) of the synthesis performed at $102 \mathrm{MPa}, 890 \mathrm{~A}$, the sample capsule height being $30.48 \mathrm{~mm}$, total weight $154.22 \mathrm{~g}$, and yield $33.23 \%$ (coefficient of transformation).

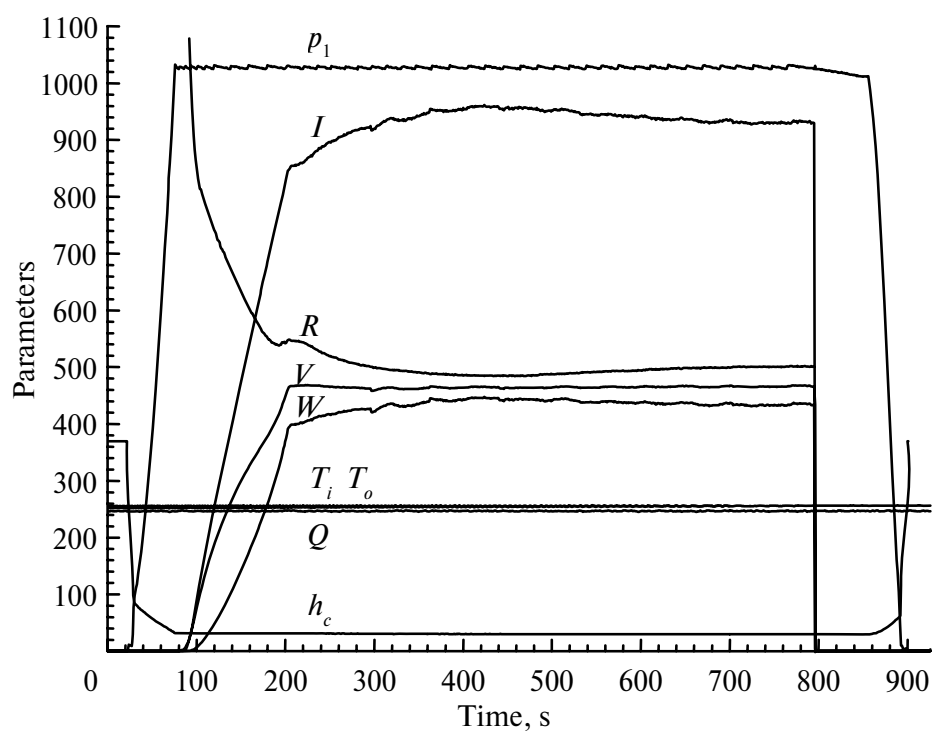

Fig. 6. Curves for synthesis performed at $p_{1}=103 \mathrm{MPa}$, free current $I_{i}=850 \mathrm{~A}, I_{\max }=963 \mathrm{~A}, I_{f}=$ $930 \mathrm{~A}$, sample height $30.26 \mathrm{~mm}$, total weight $154.01 \mathrm{~g}$, yield $=35.67 \%$ (see Figs. 1 and 5).

The difference between the frequency activation of the multiplier can also serve as an evaluator. The average number of the multiplier activation cycles per minute (cpm) during the maintenance of pressure $p_{1}(102 \mathrm{MPa})$ differs for syntheses with 
and without the diamond yield. The number of activations to maintain the diamond synthesis parameters with the diamond yield is four times higher. When the complementary pump with a variable rotation is used, this rotation can also serve as an indicator of the synthesis success. This effect is shown by the graph in Fig. 8, which can also be used in the synthesis evaluation by the CI.

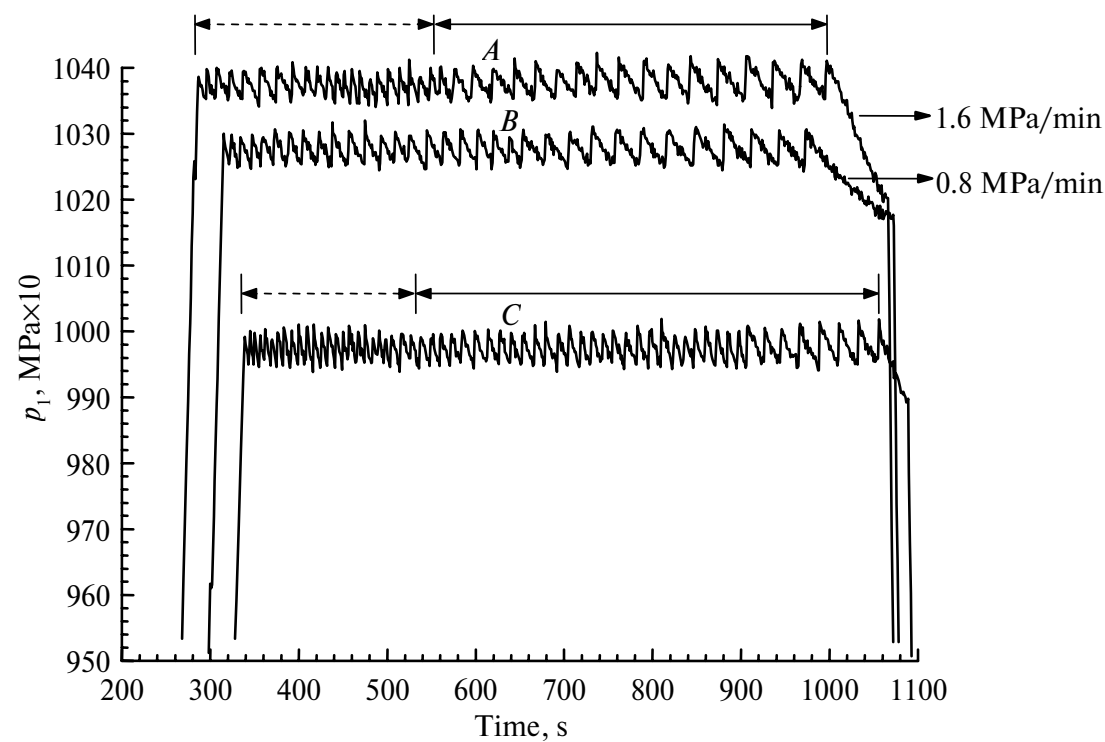

Fig. 7. Behavior of pressure curves $p_{1}$ in the following cases: low productivity with the controlled current $(A)$, without heating of the reaction mixture $(B)$, high productivity with the controlled current $(C)$.

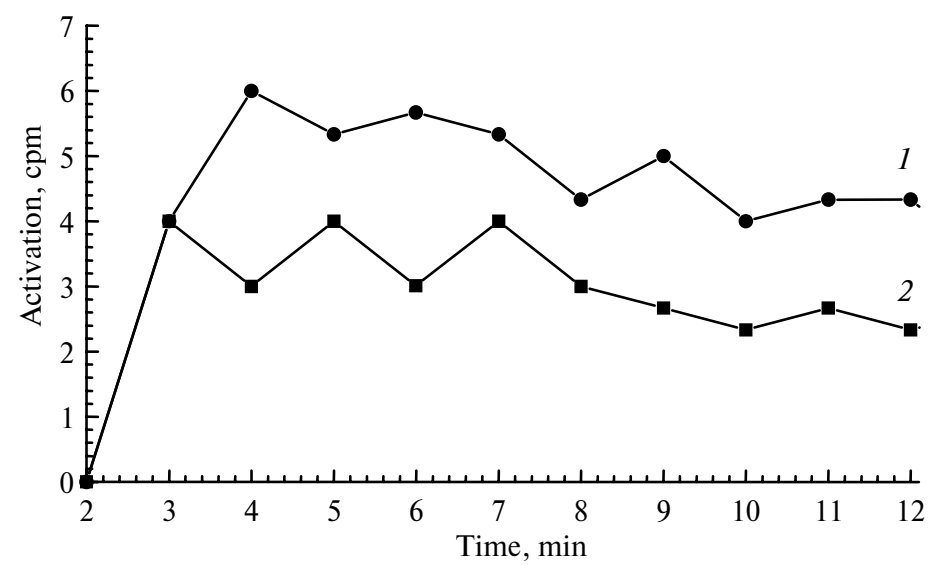

Fig. 8. Number of cycles per minute during synthesis with high productivity (l) and without it (2).

It is possible to fix the parameters of the synthesis during the process or stop it ("intervention" by the operator in the automatic process of synthesis) to ensure the increase in productivity of the synthesis in general. The first solution is more economical because it avoids the loss of material and time, but depends on the quality of the CI or the skill of the operator. The parameters that will indicate the necessity of the intervention in the process are a low or high value of the thickness; 
velocity of a change of the gasket height; and lack of the increase of the electric resistance after $200 \mathrm{~s}$ of synthesis.

Among these parameters, the distance measurement of approach between the components of a HPA allows interrupting the process in a shorter time.

In Table 2 the results of the synthesis (with a controlled current) and the change of the synthesis parameters in the course of the process are presented. The signal to change the pressure was the curve inclination of the critical thickness of the gasket formed. To attain the desired change of the temperature, the value of the electric resistance of the reaction mixture was chosen.

Table 2. Comparison of a synthesis without automatic control and with a new command, using simple diagram and pre-heating diagram

\begin{tabular}{|c|c|c|c|}
\hline Process characteristics & $\begin{array}{l}\text { Synthesis with- } \\
\text { out command }\end{array}$ & Simple diagram & $\begin{array}{c}\text { Pre-heating } \\
\text { diagram }\end{array}$ \\
\hline Pressure, GPa & $4.7 \pm 0.2$ & $4.7 \pm 0.1$ & $4.7 \pm 0.1$ \\
\hline $\begin{array}{l}\text { Temperature at the center } \\
\text { of the reaction cell, }{ }^{\circ} \mathrm{C}\end{array}$ & $1250 \pm 40$ & $1310 \pm 30$ & $\begin{array}{l}\text { pre-heating for } 2 \min \text { at } 720 \text {; } \\
\text { final heating } 1350 \pm 30\end{array}$ \\
\hline Duration, min & 13 & 10 & 9.5 \\
\hline $\begin{array}{l}\text { Amount of diamond in } \\
\text { carats obtained by the } \\
\text { operation }\end{array}$ & $\begin{array}{l}+2.0 \\
-1.0\end{array}$ & $\begin{array}{l}+3.0 \\
-2.0\end{array}$ & $\begin{array}{l}+3.0 \\
-1.0\end{array}$ \\
\hline \multicolumn{4}{|l|}{$\begin{array}{c}\text { Particle size, } \\
\% \text { of diamonds obtained } \\
\text { by an operation }\end{array}$} \\
\hline $500 / 400 \mu \mathrm{m}$ & 0.8 & 3.0 & 3.6 \\
\hline $400 / 315 \mu \mathrm{m}$ & 1.0 & 4.3 & 4.3 \\
\hline $315 / 250 \mu \mathrm{m}$ & 2.6 & 4.7 & 5.2 \\
\hline $250 / 200 \mu \mathrm{m}$ & 7.5 & 6.1 & 10.2 \\
\hline $200 / 160 \mu \mathrm{m}$ & 8.0 & 9.2 & 12.1 \\
\hline $160 / 125 \mu \mathrm{m}$ & 12.0 & 20.0 & 24.0 \\
\hline $125 / 100 \mu \mathrm{m}$ & 30.0 & 28.0 & 25.0 \\
\hline $100 / 80 \mu \mathrm{m}$ & 20.5 & 13.2 & 10.3 \\
\hline $80 / 63 \mu \mathrm{m}$ & 13.7 & 9.4 & 4.1 \\
\hline $63 / 40 \mu \mathrm{m}$ & 3.9 & 2.1 & 1.2 \\
\hline \multicolumn{4}{|l|}{$\begin{array}{l}\text { Morphology of the obtained } \\
\text { diamonds, mass \% }\end{array}$} \\
\hline Crystals of correct habit & 13.1 & 16.2 & 10.8 \\
\hline Grains of angular shape & 23.4 & 25.6 & 33.7 \\
\hline Elongated grains & 29.5 & 35.3 & 29.2 \\
\hline Grains of a laminar fashion & 34.0 & 22.9 & 26.3 \\
\hline
\end{tabular}

The theoretical study was made on the basis of experiments that enabled to determine the level curve that describes the productivity with independent variables $p_{1}$ and $I$, to support the obtained results, and justify the perspective of the CI use. Five repetitions on the central point of the CCP allowed determining the average relative error of 3.05 . 
Figure 9 shows the level curve of the productivity. This curve indicates that under the conditions employed the higher productivity is in the region above $940 \mathrm{~A}$ and 103.5 MPa. These results show that the initial temperature of the synthesis process should be $1350^{\circ} \mathrm{C}$ at a pressure $p_{2}$ at least of $4.7 \mathrm{GPa}$. Analyzing the level curve, we see that the highest productivity could be achieved with a pressure of 104.8 MPa and electric current of $960 \mathrm{~A}$.

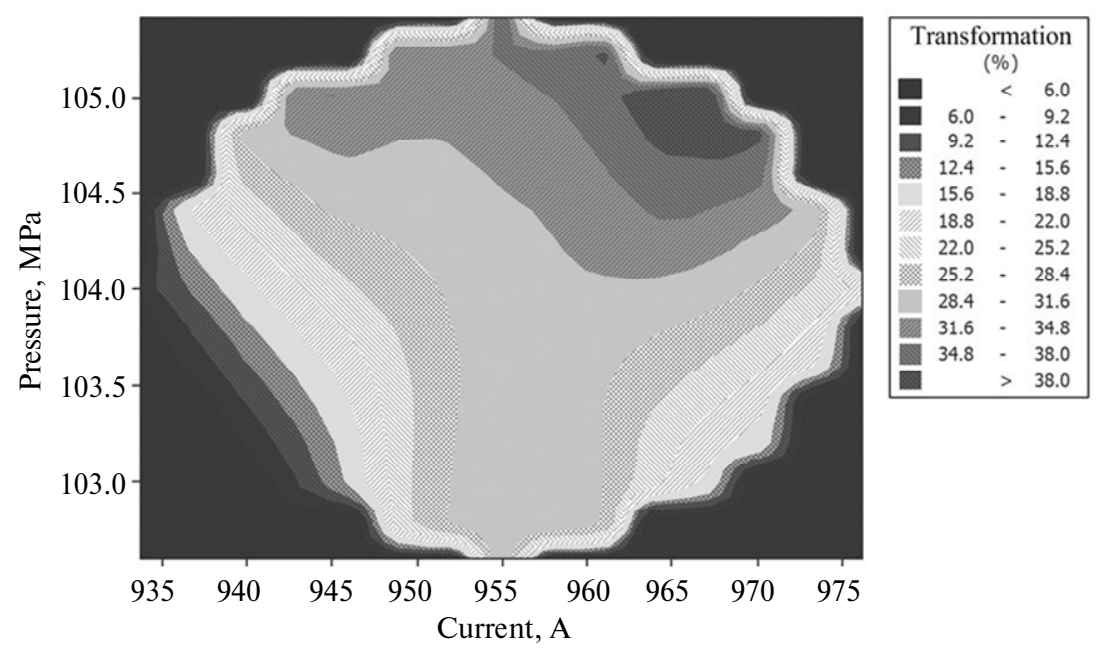

Fig. 9. Pattern of the 10-min productive synthesis using variable parameters.

The analysis of the recorded data of the indirect parameters such as flow, input and output temperatures of the water cooling the HPA, temperature of the HPA parts, shows that they also have an impact on the process results. It is necessary to maintain the temperature of the anvils and of the HPA components until level $50^{\circ} \mathrm{C}$ before the installation into the press. Under the real conditions of the carried out studies, it was not possible to maintain this equality in the time of synthesis.

The influence of the new automation system on the process of diamond synthesis is shown in Table 3.

Table 3. Results of the automatic synthesis lasting $10 \mathrm{~min}$

\begin{tabular}{|c|c|c|c|c|c|c|}
\hline $\begin{array}{l}\text { Synthesis } \\
\text { products }\end{array}$ & $\begin{array}{l}\text { Initial height } \\
\text { of the capsule, } \\
\mathrm{mm}\end{array}$ & $\begin{array}{c}\text { Initial weight } \\
\text { of the capsule, } \\
g\end{array}$ & $\begin{array}{l}p_{1} \\
\mathrm{MPa}\end{array}$ & $\begin{array}{l}\text { I } \\
\mathrm{A}\end{array}$ & $\begin{array}{c}\text { Critical } \\
\text { height of a } \\
\text { gasket, mm }\end{array}$ & $\begin{array}{c}\text { Average } \\
\text { productivity } \\
\text { per operation, } \\
\mathrm{g}\end{array}$ \\
\hline $\begin{array}{l}\text { Without diamonds, } \\
3 \text { units }\end{array}$ & 30.28 & 151.56 & 102 & 955 & 2.88 & 0 \\
\hline $\begin{array}{l}\text { Diamonds at the } \\
\text { center, } 7 \text { units }\end{array}$ & 30.36 & 147.44 & 102 & 955 & 2.90 & 3.2 \\
\hline $\begin{array}{l}\text { Diamonds at the } \\
\text { periphery, } 10 \text { units }\end{array}$ & 30.42 & 154.52 & 102 & 955 & 2.95 & 4.1 \\
\hline $\begin{array}{l}\text { Diamonds in the } \\
\text { entire section, } \\
30 \text { units }\end{array}$ & 29.80 & 148.61 & 102 & 955 & 2.70 & 5.8 \\
\hline
\end{tabular}


The above results show that the indicated parameters have considerable influence on the productivity, because there are variations even maintaining the main parameters $\left(p_{1}, I\right.$ and $\left.t\right)$ constant in all experiments and indirectly near the equilibrium line in the phase diagram of carbon. For this reason, it is necessary to carry out further investigations to develop a more effective CI.

\section{SINTERING OF A cBN COMPOSITE}

25 samples of composites based on $\mathrm{cBN}$, almost cylindrical in shape with a diameter of $5 \mathrm{~mm}$ were produced.

According to the supervisory program of the 630-ton hydraulic press, the more complex record of the graphs of sintering that presented the real values of pressure $p_{1}$ and power $W$ during the process was done. Two graphs are presented for unicycle and three-cycle sintering (Figs. 10 and 11).

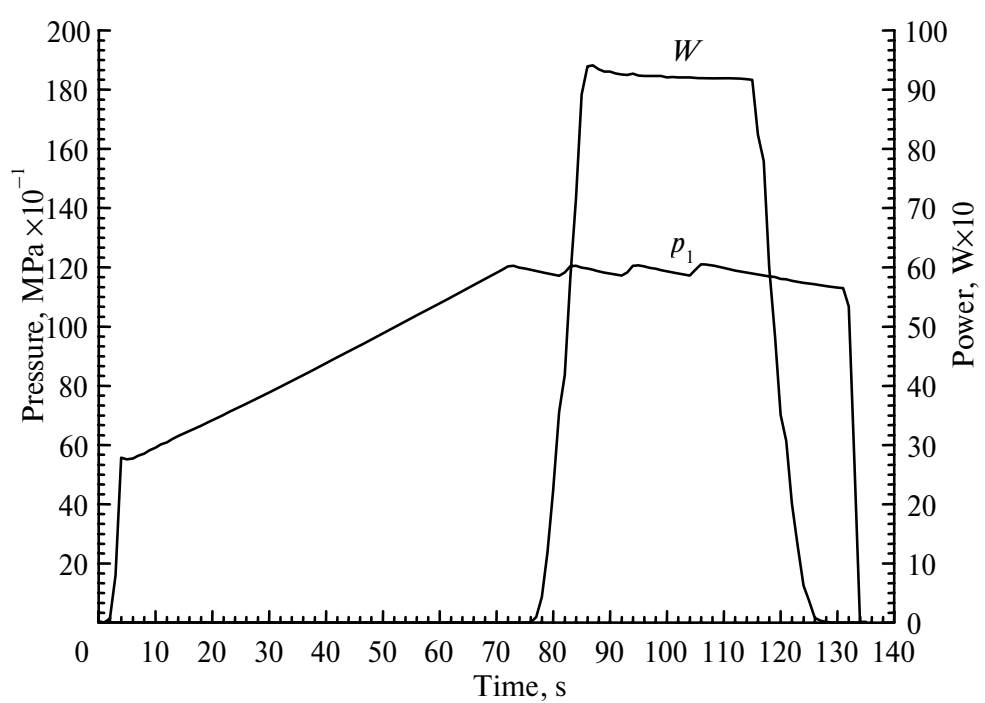

Fig. 10. Curves of sintering $\mathrm{cBN}$ at a pressure of $p_{1}$ and power $W$, sample 1.2.

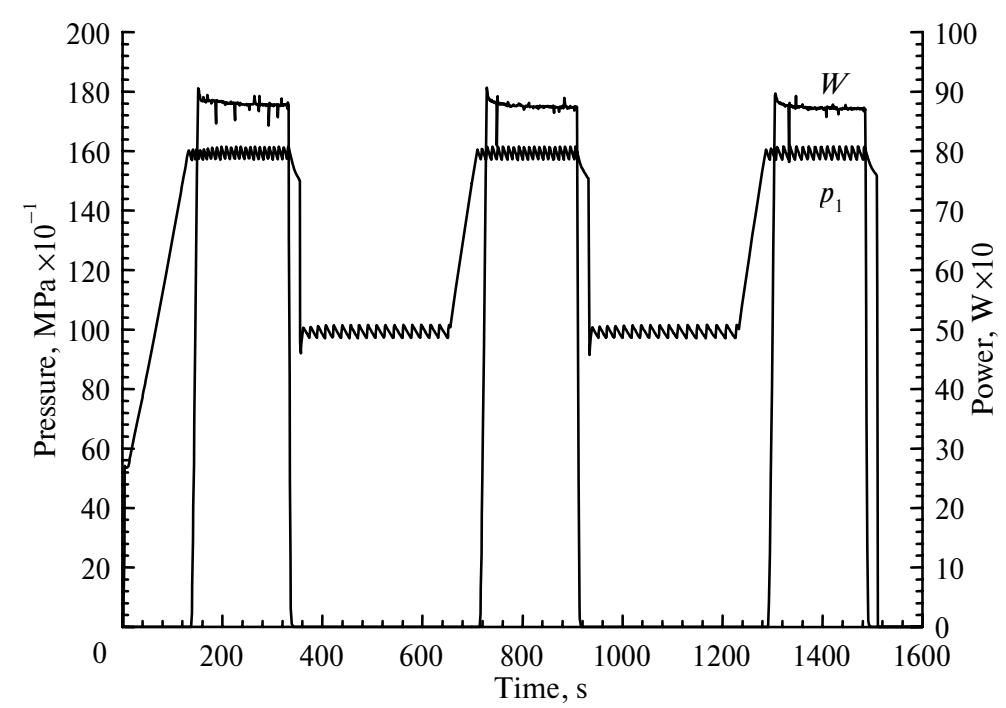

Fig. 11. Curves of the parameters of sintering cBN for three cycles under the action of pressure $p_{1}$, and power $W$, sample 5.2. 
The period of the high pressure application for each cycle was of $2.5 \mathrm{~min}$ to compensate the time spent for the increase and decrease of the power, each cycle lasted for a period of $6 \mathrm{~min}$, which includes the increase of the pressure up to the operating level (1.2 min), maintaining the pressure for $2.5 \mathrm{~min}$, and decrease pressure for $2.3 \mathrm{~min}$. The time of the real sintering (simultaneous action of pressure and temperature) was 2 min.

In all graphs, there were average variations of $\pm 0.2 \mathrm{MPa}$ and $\pm 3.0 \mathrm{~W}$ at a level of sintering. The greatest high-pressure variation was in sample 3.2 with variations of $\pm 0.5 \mathrm{MPa}$ and $\pm 30 \mathrm{~W}$.

The graphs show that there was not a uniform velocity of the pressure reduction between the stages of high and low pressure $p_{1}$, which caused a malformation of the level of low pressure (10 MPa in the master cylinder). For sample 5.2, the pressure reduced to a value of $9.2 \mathrm{MPa}$. Thus, it is understood that the reduction period of 1 min between the levels of maximum and minimum pressure $p_{1}$ has not been sufficient for the effective formation of the pressure minimum level, since the high speed of reduction did not allow the software to perform the control as scheduled.

The positive influence of the cyclic application of the sintering parameters, in the automatic system, is connected both with the increase of samples density and the increase of mechanical characteristics. This is caused by a martensitic recrystallization of the binder and a decrease of space between the cBN grains. The best results were exhibited by samples treated in three cycles. The microhardness increased the by $18 \%$.

\section{CONCLUSIONS}

The development of the new command for special presses of UENF made it possible to mark exactly, which parameters of synthesis and sintering are responsible for the stability and perfection of the processes mentioned. The possibility to record 11 direct and indirect parameters gives a great opportunity to assess the influence of parameters, which are not monitored, and to make a proposal to create the appropriate algorithms of the future CI.

The behavior of the recorded curve shows that in the case when the HPA of an anvil with a central cavity type is applied, the synthesis process is unstable, because of many phenomena. A collection of data related to the operating conditions and their results can be processed using a data mining algorithm to identify the interrelation of these phenomena.

The direct real parameters $I$ and $p_{1}$ and the effectiveness of the process depend on the following indirect parameters: a size variation of a deformable capsule, density of the reaction mixture and its electrical resistance; properties of other components of the reaction cell; initial temperature of the anvils, a speed of cooling the HPA, and plastic deformation of the working surfaces of the HPA anvils.

The construction of the HPA used creates a change of the pressure during heating of the reaction cell accompanied by a reduction of the critical thickness of the gasket formed. A pressure increase due to warming (thermal expansion) was not recorded.

The curve of measuring the distance between the components of HPA during the generation of high pressure and temperature can serve as an indicator of the interruption of the process with no productivity and also can serve as an indicator of the value of high pressure $p_{2}$ within the compression chamber at room temperature. 
Based on the analysis of the information obtained from the tests of the command, we can state that the measuring of the distance between the anvils may enable the construction of the calibration curve of the pressure inside the compression chamber of HPA. This measuring of the distance may also establish a new parameter for pressure control, state the time of disconnection of the press in case of a rapid ejection in the form of explosion, and indicate a variation of the compression chamber volume.

As it is impossible to eliminate the casualties, the new command of the 2,500ton press is enabling the correction of the $p, T$-parameters during the automatic process of synthesis or stopping it, even thus increasing the productivity of synthesis per minute (from 6 to $8 \%$ ).

The new command allowed increasing the process productivity by a factor of 1.2, increasing the lifetime of the HPA by $10 \%$, improving security, and, especially, providing data for scientific analysis in studies of high pressure.

In the case of sintering superhard material, the new command and the research have shown the ability, for example, to carry out very complex procedures.

Concluding the analysis of the results obtained previously with new automation system of the 630- and 2,500-ton presses for production of superhard materials, we can say that there is a perspective of the development and application of CI to increase quality and productivity of superhard materials on an industrial scale for HPA of the anvil with a central cavity type.

Розроблено нову систему управління пресами зусиллям 630 і 2500 тонн. За допомогою иієї системи стало можливим визначити нові параметри, щзо пов'язані з тиском і температурою, і вплив на них певних факторів. Крім того, інші параметри, такі як висота ущільнення, щчо утворюється, електричний опір реакиійної комірки $і$ частота активації насоса або мультиплікатора, можуть бути важливими показниками удосконалення технології отримання надтвердих матеріалів при використанні обчислювального інтелекту.

Ключові слова: високий тиск, надтвердих матеріалів, синтез, спікання, прес, апарат високого тиску, управління.

Разработана новая система управления прессами усилием 630 и 2500 тонн. С помощью этой системы стало возможным определить новые параметры, связанные с давлением и температурой, и влияние на них определенных факторов. Кроме того, другие параметры, такие как высота образующегося уплотнения, электросопротивление реакиионной ячейки и частота активачии насоса или мультипликатора, могут служить важными показателями улучшения технологии получения сверхтвердых материалов, используя вычислительный интеллект.

Ключевые слова: высокое давление, сверхтвердых материалов, синтез, спекание, пресс, аппарат высокого давления, управление.

1. Shulzhenko A. A., Maslenko Yu. S. et al. Study of the pressure change in conditions of high pressure during the synthesis of super hard materials // Vliyanie vysokikh davlenii na materialy (The influence of high pressure on the substances). - Kiev: IPM AN UkrSSR,1977. P. $113-117$.

2. Novikov N. V., Prikhna A. I, Borimsky A. I. Steel high-pressure apparatus for synthesis of superhard materials // Proc. 8th Int. Conf. AIRAPT and 9th EHPRG Int. Conf. on High Pressure Research, Sweden. - Uppsala: Univ. of Uppsala, 1983. - Vol. 2. - P. 493-498.

3. Potemkin A. A., Poliakov V. P. The evolution of pressure during diamond synthesis in the high pressure apparatus // High Pressure Sci. Technol. - 1998. - 7. - P. 1004-1006. 